\title{
Shareholder's Democracy under the Nigerian Company Law
}

\author{
Elisabeta Smaranda Olarinde1, Udosen Jacob Idem ${ }^{2 *}$ \\ ${ }^{1}$ College of Law, Afe Babalola University, Ado Ekiti, Nigeria \\ ${ }^{2}$ Department of Private and Business Law, College of Law, Afe Babalola University, Ado Ekiti, Nigeria \\ Email: ^idemudosen@abuad.edu.ng
}

How to cite this paper: Olarinde, E. S., \& Idem, U. J. (2020). Shareholder's Democracy under the Nigerian Company Law. American Journal of Industrial and Business Management, 10, 1013-1038. https://doi.org/10.4236/ajibm.2020.105068

Received: November 4, 2019

Accepted: May 26, 2020

Published: May 29, 2020

Copyright (๑) 2020 by author(s) and Scientific Research Publishing Inc. This work is licensed under the Creative Commons Attribution International License (CC BY 4.0).

http://creativecommons.org/licenses/by/4.0/

(c) (i) Open Access

\begin{abstract}
The performances of corporate entities in Nigeria leave much to be desired (Onyekelu, 2019). Reasons for company failure are mismanagement and fraudulent practices by the directors who oversee the day-to-day management of the company and lack of effective supervisory powers of the shareholders over the activities of directors. This paper examines the shareholder's democracy over the board of directors in modern corporate governance in $\mathrm{Ni}$ geria. The article adopted expository, analytical and comparative methods in conducting this research. Part of the findings of the paper is that the directors who control the day-to-day affairs of the company also control the machinery for company meetings, which is one of the major ways in which shareholders involve themselves in corporate governance. The authors suggest that to guarantee shareholders franchise in Nigeria, Sections 217, 230 and 232(1) of CAMA should be amended to give shareholders the power to issue notices of meetings (Onyekelu, 2019).
\end{abstract}

\section{Keywords}

Shareholders' Democracy, Corporate Organs, Proxy System, Directors and Meetings, Nigeria

\section{Introduction}

In the traditional corporate governance model, the shareholders or the members in general meeting stand as the highest authority. Fundamental matters relating to structural changes in the company are decided by the shareholders (sections 44 - 48, 102 CAMA). With the emergence of large corporations and the separation of ownership and control, there appears to be an erosion of the traditional corporate governance. Under the new dispensation, the board of directors has 
acquired more powers. It is not answerable to the members in a general meeting when acting within the powers conferred upon it by the company's constitution (sections 65 (4), CAMA).

The most acceptable means of the corporate monitor is through the general meeting. Although the general meeting is not saddled with management powers explicitly, they still perform some democratic roles over the exercise of management powers by the board of directors. The reason is that the members in the general meeting are those that really have a pecuniary interest in the company, as the success of such a company enhances their earning. In contrast, the directors have nothing to lose in the event of mismanagement, except where they are also members of the company (Amupitan, 2008).

The problem that this paper sets out to address is the effectiveness or otherwise of the supervisory role of the general meeting by shareholders to control the activities of the board of directors for the efficient running of the company. There seems to be some controversy as to whether the shareholders can effectively supervise their directors. The truth about the supervisory role of the general meeting over the board of directors in modern corporate governance is that so much has been written and said about the concept, ranging from writing of scholars and eminent jurists to the case law, the debate on appropriateness and effectiveness of shareholders democracy in controlling the board of directors is far from being over, and that is the concerned of this paper.

\section{The General Concept of Democracy}

It is pertinent to state that since a company is made up of different individual with varying interests, it is usual to run it on democratic principles. But before we proceed to discuss shareholder's democracy in corporate governance, I think it would not be out of place to attempt a general definition of the term democracy. The word "democracy" was derived from two Greek words: "demos", meaning the people and "cracy" meaning the "government" (Akindele, 1994). Democracy is, therefore, simply put, the people rule, or a form of government where power resides in the people.

Black's Law Dictionary (Garner, 2004), defines democracy as:

That form of government in which the sovereign power resides in and is exercised by the whole system of free citizens directly or indirectly through a system of representation as distinguished from monarchy (the rule of monarch, or aristocracy) (the rule of a privileged class) or an oligarchy (the rule of a junta),

while the Oxford Advanced Learner's Dictionary (Hornby, 2000) defines democracy as:

The government which encourages and allows majority rule accompanied by respect for the rights of minorities.

In ordinary parlance, democracy is said to exist in a country if the voters are 
allowed to choose freely, their leaders. Thus, after the election, their leaders must be responsible, responsive and accountable to the electorate. As a matter of fact, the democratic rule permits majority decisions, in all its deliberations while at the same time protects the interest of the minority groups. For these principles to work well, first there must be obedience to the law and democratic process. That is to say, there must be a constitution which spells out the mode of elections, how political leaders should be appointed, tenure of office, establishment and allocation of powers and so on. Secondly, democracy entails that once the people have voted, made their choices, the candidates and their political parties should accept and respect, the verdict of the electorate and the government, for its part, must deliver the dividend of democracy which it promised to pursue.

In the same vein, modern companies can be seen in the context of democracy. However, in corporate democracy members or shareholders of a company who are the real owners of the company are regarded as the electorate while the board of directors forms the executive arm of the government of the company. Its constitution comprises the memorandum and articles of association and the general law of the land. Shareholders through those provisions which provide for annual elections of directors and for shareholders vote upon basic changes if needs be is said to form the basic concept of shareholders democracy. However, as in civil democracy corporate government has its own problems which tend to make people believe that shareholder's suffrage is fiction and not reality. It is instructive to note that the applicability of this concept is built on the relevant provisions of various laws of different countries which provide for the Annual General Meeting (AGM) of the companies for the election or removal of directors indirect voting by the majority of the shareholders or by proxy voting (Section 262 of Companies \& Allied Matters Act, 2004). Also, the AGM confers on the shareholder's certain powers which if exercised, are important in the administration of a company (Adegbite et al., 2010). These powers which are exercised at the General Meeting, including the power to appoint and remove directors, approve the remuneration of authors' and even the power to institute legal proceedings to prevent the directors from entering into illegal or ultra vires actions, the power to declare dividends, presentation of financial statements and the reports of Directors and Auditors, the election of directors in place of retiring ones, fixing remuneration and appointment of members of the audit committee (Onuoha, 2015). The General Meetings thus afford an opportunity for shareholders to supervise the management of the company. Since the Articles of Association regulates the management of the company, and the power to alter these articles lies in the shareholders, the shareholders can alter the Article for their own protection (Onuoha, 2015). And can also prevent the directors from perpetuating fraud (Dorothy, 2015).

In England, the Companies Act of 2006 makes a far-reaching provision for Annual General Meeting (AGM). Section 336 of the said Act states:

Every public company must hold a general meeting as its annual general 
meeting in each period of 6 months beginning with the day following its accounting reference date (in addition to any other meetings held during that period) (Arden \& Arden, 2016).

Subsection (3) provides that:

If a company fails to comply with subsection (1), an offence is committed by every officer of the company who is in default.

The law in subsection (4) imposes penalties for defaulters thus:

A person guilty of an offence under this section is liable-(a) on conviction on indictment, to a fine; (b) on summary conviction, to a fine not exceeding the statutory maximum (Arden \& Arden, 2016).

Section 337 provides for the notice of AGM as follows: (1) A notice calling an annual general meeting of a public company must state that the meeting is an annual general meeting; (2) An annual general meeting may be called by shorter notice than that required by section 307 (2) or by the company's articles (as the case may be) if all the members entitled to attend and vote at the meeting agree to the shorter notice.

In Nigeria, Section 213 of the CAMA provides for annual General Meeting as follows:

Every company shall in each year hold a general meeting as its annual general meeting in addition to any other meeting in that year, and shall specify the meeting as such in the notices calling it; and not more than 15 months shall elapse between the date of one annual general meeting of a company and that of the next (Cap C20 LFN, 2004).

Section 213(5) of the same law states that:

If default is made in holding a meeting of the company in accordance with subsection (1) of this section, or in complying with any directions of the Commission under section (2) thereof, the company and every officer of the company who is in default shall be guilty of an offence and be liable to a fine of N500, and if the default is made in complying with subsection (4) of this section, the company and every officer of the company who is in default shall be liable to the fine of N25 (Cap C20 LFN, 2004).

At this meeting, the members are at liberty to question the directors on their accounts, their reports and on the company's position and prospects. It is also at this meeting that some directors will come up for re-election. This, itself has a restraining influence on the activities of directors if they want to be re-elected. More importantly, the members can in this meeting remove any director by an ordinary resolution with special notice irrespective of what the articles of association say or any special contract that may exist between the members and the directors (Section 262(1) of the Companies and Allied Matters Act, 2004). This reasoning has perhaps informed the opinion of the English court of Appeal in 
the case of Isle of Wright Railway v Tahourdin (1883) 25 Ch. D. 320, CA) where Hislordship Cotton L J (as he then was) said that:

It is a very strong thing indeed to prevent shareholders from holding a meeting of the company when such meeting is the only way in which they can interfere if the majority of them think that the course is taken by the directors, in a matter intra vires of the directors, and is not for the benefit of the company.

Also, in the Nigerian case of Yalaiju Amaye v. AREC (1990)4 NWLR (pt. 145) 422) the court held that the ultimate power to control the affairs of the company rests squarely on the shareholders in General Meeting.

One point that has to be made at this stage on the control of corporate powers by the General Meeting vis-a-vis that of the Board of Directors; is that primarily, the members at general meeting shall have the power to re-elect or reject directors and appoint new ones (Section 248 CAMA), while the board of directors shall have the power to appoint new directors to fill any casual vacancy arising out of death, resignation, retirement, or removal (Section 249 (1) (2) and (3) CAMA).

Where a part-time position is filled by the directors, the individual might be ratified by the general meeting, and if not all that endorsed, he will forthwith stop to be a director. The directors may expand the quota of directors inasmuch as it doesn't surpass the most extreme permitted by the articles; however, the general meeting will have the ability to increment or lessen the number of directors by and large and may decide in what sequence the directors will resign, gave that such decrease will not nullify any earlier act of the displaced director. By the intendment of the Act's provisions identified above, literally and in theory, the members in general meeting occupy a supreme controlling position. This is because while the general meeting can remove the directors of the entire board, the general meeting is itself not removable by the board of directors. Furthermore, shareholders may by ordinary resolution passed at a general meeting of the company remove a director from office, even before the expiration of the director's tenure, notwithstanding anything contained in the articles of association or any agreement between the company and the directors (Iwuchukwu v. Nwizu (1999) 17 NWLR (pt. 357).

From the above, where the general meeting disapproves the manner the directors are conducting the affairs of the company, it can intervene through special resolution, or by altering the articles, or by removing the directors. However, the general meeting cannot exercise this power if it is contrary to the provisions of the articles. Where the company defaults in holding the AGM, any member may complain to the Corporate Affairs Commission (CAC), and the CAC may give direction. On the calling of the meeting or consequential direction as the commission thinks expedient. The Corporate Affairs Commission may also provide direction that such members should apply to the court for necessary orders (Section 213 (2) of CAMA). Thus, in Longe v. F.B.N (2010) 6 NWLR (pt 11891 
at 43), the Supreme Court held that:

The members of a company at the annual general meeting shall have the power to re-elect or reject directors and appoint new ones. In the event of all the directors and shareholders dying, any of the personal representatives shall be able to apply to the court for an order to convene a meeting of all the personal representatives of the shareholders entitled to attend and vote at a general meeting to appoint new directors to manage the company, and if they fail to convene a meeting, the creditors if any shall be able to do so.

Similarly, in the case of Re Dahiru Wada, (2000) FWLR (pt. 18) 214 at pp. 229-233). The Court of Appeal held that except on the court's own motion, only a member of the company, who would be entitled to vote at the meeting, could properly apply to the court for an order that a meeting of the company be called, held, and conducted in such a manner as the court thinks fit. Correspondingly, only a member of the company who would be entitled to vote at the meeting of the company could oppose such application before the court. Furthermore, in the case of Okeowo v. Milgore (1979) 11 S.C. 138), the Supreme Court per Idigbe JSC (as he then was) declared that:

A resolution of the proper majority of shareholders in the general meeting is the proper mode of declaring the will of the corporation.

It is pertinent to note that it is mandatory for directors to convene Annual General Meeting (2019 (3) TMI 1187: https://www.taxmanagementindia.com/). It is also noteworthy that CAMA (Cap. C20, LFN, 2004) does not make adequate provision for the consequences of default in holding the meeting. It merely provides in Section 213(5) that the company and any of its officers who are in default shall be liable to a fine of N500 in respect of a default of Section 213(1) and (2) if the default is made in complying with sub-section (4) of the Section, the company and every officer of the company who is in default shall be liable to a fine of N25. It is important to observe that imposing the above paltry fines is not enough to deter directors and managers who are highly paid personnel; rather, they would like to pay the paltry fines instead of holding the meeting especially in a situation where holding such meetings is against their interest. It is suggested that a stiffer penalty be imposed, such that the management which fails to hold the meeting as and when due shall be liable to relinquish the position.

Although it is desirable that the shareholders should not interfere with the day-to-day running of the company (Scott v. Scott (1943) 1 All E.R. 582), one wonders whether the Annual General Meeting should be merely an annual event. The general meeting seems to be the most important opportunity for the shareholders (the electorate) to exercise their franchise. Here again, it is recommended that it will probably be more equitable if the general meeting is held at least twice a year.

It is also mandatory in law for directors to convene an extraordinary meeting if the need arises. The extra-ordinary meeting is designed to take urgent matters that have arisen and which cannot wait till the next Annual General Meeting. 
Thus, matters discussed at the extra-ordinary meeting are regarded as special. (Ekpo, 2005) The position of the law in England has been that any meeting other than the Annual General Meeting shall be called an extra-ordinary meeting and it may be convened by the directors at the instance or request of holders of not less than one-tenth of the paid-up capital carrying voting rights. In Nigeria, a similar provision is made in Section 215(1) of CAMA, which provides for calling of extra-ordinary general meeting whenever the need arises. In law, both the directors and members holding at least one-tenth of the paid-up capital with voting rights may convene the extraordinary meeting.

The directorate may summon an extraordinary general meeting at whatever point it esteems appropriate. On the off chance that whenever there are not within Nigeria, adequate directors equipped for acting to shape a legal minimum, any director may assemble an extraordinary general meeting.

The court may suo motu, that is, on its discretion, or upon application of a person entitled to vote at such meetings, order a meeting to be called, and held where it is impracticable for any reason to call, or conduct a meeting of the company. Both directors and ordinary members are entitled to apply to the court for the holding of such a meeting.

The CAMA in Section 211 CAMA provides that every public company must hold a general meeting of its members within six months of its incorporation. This meeting shall be designated "statutory meeting", and failure to comply with these provisions of CAMA renders the company and every officer liable upon conviction. It may also be a ground for winding up of the company by the court (Sections 212 and 408 (b) CAMA). The essence of a statutory meeting is to avail the members the opportunity of having the first progress report of the performance of the company from the company directors and promoters (Orojo, 1992). A statutory meeting is held once in the existence of a company to satisfy the provision of the Act, within the first six months. It must be clearly indicated that it is a statutory meeting. All other requirements pertaining to the convening of the statutory meeting must be complied with.

A statutory report must, at least 21 days before the date of the meeting, be forwarded to every member of the company; where any member wishes any resolution to be passed on any matter arising out of the statutory report, he/she is required to give 21 days' notice from the date on which the statutory report was received to the company of his intention to propose such resolution (Section 211 (2) and (3) of CAMA). Section 216 of CAMA provides that the statutory meeting shall be held in Nigeria and the report must be certified by at least two directors.

It would be noticed that the whole concept of shareholders' democracy is based essentially on how the shareholders in a company's meeting exercise a supervisory role over the board of directors in a bid to attain the objective of the organization and to build and strengthen accountability, credibility, transparency, integrity and trust in the system. Accordingly, in order to ascertain whether the shareholders actually in practice have the effective exercise of control over the management of the company, it would not be out of place to discuss the 
proceedings at the meeting, what procedures and rules are followed, the length of notice, the use of proxy system and quorum. But before then, a quick look at what the term "meeting" is all about is inevitable.

Black's Law Dictionary (Garner, 2004) defines a "meeting" as:

an assembly of persons, especially to discuss and act on matters in which they have a common interest, while

The Oxford Advanced Learner's Dictionary (Hornby, 2000) defines "meeting" as:

an occasion where people come together to discuss or decide on matters of common interest.

CAMA, on the other hand, fails to define the term "meeting", but in explaining what a meeting is all about, His Lordship, Lord Justice Mellish in the English Case of Sharp v. Dawes stated inter alias as:

the coming together of at least two persons for the purpose of discussing and acting upon some matter or matters in which they have a common interest.

From the wording of Section 232(2) of CAMA, the word "meeting" connotes that there should be one-third of the total number of members of the company or 25 members present in person or by proxy. The same Section of the Act goes further to define a meeting as follows:

Where the number of members is six or less, the quorum of the meeting shall be two members.

In the light of the foregoing definitions of a meeting by the scholars and eminent jurists, it is clear that for all types of the meeting of a company to be valid there should be at least two persons to constitute a meeting.

\section{The Relationship between the Board of Directors and the General Meeting}

At common law, the distribution or allocation of powers depends in the most part, on the memorandum and articles of association of the company (Pranchi, 2015). Consequently, the question as to who controls the company, the general meeting or the board of directors has also been a source of controversy in other commonwealth countries and has given rise to various judicial interpretations in a number of cases since the $19^{\text {th }}$ century. Initially, the general consensus appeared to have been that the general meeting was the superior organ of the company and the board of directors was merely an agent of the company subject however to the control of the general meeting. This thinking influenced the court in the case of Isle of Wright Rly v. Tahourdin (1883, 25 Ch.D. 320) when it refused to grant an injunction sought by the directors to restrain the holding of a general meeting aimed at appointing a committee to re-organize the manage- 
ment of the company. The observation of cotton L. J., in this case, is illuminating:

It is a very strong thing indeed to prevent the shareholders from holding a meeting of the company when such a meeting is the only way in which they can interfere if the majority of them think that the course taken by the directors on a matter ultra vis of the directors is not for the benefit of the company (Wikipedia: https://en.wikipedia.org Wright Rly v. Tahourdin).

Later courts realized the need to grant to the directors some level of superiority in the management of the company if the company is to function effectively, and so; they leaned in favour of the contents of the Articles of Association.

According to this latter view, if the articles give the director's management powers, such powers cannot be interfered with by the shareholders in the general meeting (Quin Axtens v. Salomon 1908 Ch 311). In shaw \& Sons (Salford) Ltd v. Shaw, (1937 2 K.B. 113) the court emphasized that management powers vested in the board of directors by the articles can only be exercised by them alone. The general meeting cannot usurp such powers; neither can the directors usurp powers vested in the general meeting by the articles. Instead of a conflict with the directors, or outright interference with the functions of the directors, the general meeting can alter the articles or refuse to re-elect the directors when their tenures expire. It can even remove the directors and elect new ones (Baron v. Potter (1914) 1 Ch. 895, Foster v. Foster (1916) Ch. 532).

Similarly, in the case of Automatic Self-cleaning Filter Syndicate v. Cunningham ((1906) 2 C.h. 34) where it was clearly said that the division of powers between the board of directors and the members of the company in general meeting depended, in the case of registered companies, entirely on the construction of the articles of association and that where powers had been vested in the board, the general meeting could not interfere with their exercise, the articles were held to constitute a contract by which the members had agreed that the "directors and directors alone should manage the day-to-day business of the company" (Automatic Self-cleaning Filter Syndicate v. Cunningham (1906) 2 C.h. 34). In this case, the company refused to carry out a sale agreement resolved upon by the company in a general meeting because, in the directors' view, it was not in the best interest of the company. The directors relied for support of their decision upon the articles which delegated to them all powers of management. The members argued that the articles are subject to the general rule that agents must obey the directive of their principals. The Court of Appeal refused this contention holding that the resolution of the general meeting was a nullity and could, therefore, be ignored (Show v. show 1953, 3 K.B 113; Bamford v. Bamford, 1968, 3 W. LR. 317). Consequently, where the general management of the company is vested in the directors, and so long as they are acting at a properly constituted board meeting and within the powers conferred by the memorandum and articles of association, a resolution of the company, in general, is not binding upon them (Grmaphone and Typewriters Ltd. v Stanley, (1908), 2 K.B 89). Barnes, in 
his book, Cases and Materials on Company Law, addresses the issue of corporate governance under the rubric "management" (Barnes, 1992). The learned author asserts that the general meeting of the company-whether statutory, annual, extraordinary or court-directed-is a vital organ of the company. He adds that the general meeting provides an occasion for shareholders to air their views on company matters and take effective action, within their powers, if they are dissatisfied with company policies, practices or its board of directors or officers (Barnes, 1992).

So much was gained in reading this book during research as we place significant reliance on it. However, this book did not cover the effectiveness or otherwise of Shareholders Democracy over the board of directors in modern corporate governance, which is to be covered in this paper.

Amupitan's Corporate Governance: Models and principles is one book that is almost on a direct point to this paper (Amupitan, 2008). He states that corporations are so important that they dominate the economic sphere of every nation. The food we eat, the water we drink, the household materials, the clothes we wear and the vehicles we drive-all come from companies. He says that the time is fast coming when companies will be more important than sovereign states. $\mathrm{He}$ argues that the global economic recession of 2007-2009, which witnessed the collapse of some of the world biggest corporations, among other factors, brought the importance of good corporate governance to the force. He adds that:

The collapse did not only lead to the demise to those corporations but also caused heavy loss of revenue to the government, loss of employment to the employees, loss of means of livelihood to their suppliers, loss of money to the creditors of those companies, loss of services to the general public, loss to shareholders and directors that bear the loss from the failure of the company (Amupitan, 2008).

Even then, the learned author did not state how the good corporate governance code provides clear basis ground for effective corporate governance.

Ekpo says inspite of the CAMA attempt at separating the functions of the shareholders and that of the board of directors, in practice, the issue of superiority of one over the other in managing the company often arises (Ekpo, 2005). This is because both organs have vital responsibilities in the organization. Moreover, some judicial pronouncements, instead of helping to arrest the conflict, have rather fuelled it (Ekpo, 2005). The learned author did not mention what caused the rivalry between the two organs, which is to be covered in this work.

The Company and Allied Matters Act which is the principal legislation on companies' law and practice in Nigeria equally recognized the issue of corporate governance. Section 63 of CAMA states among other things that:

A company shall act through its members in general meeting or its board of directors or through officers or agents, appointed by, or under authority 
derived from, the members in general meeting or the board of directors.

Gower put the legal position beyond doubt when he said:

The old idea that the general meeting alone is the company's organ and the directors merely the company's agents and servants at all times subservient to the general meeting seems no longer to be the law as it is certainly not the fact (Gower, 1997).

These writers associate themselves with the view expressed by Gower that the directors must be given supremacy in matters of the day-to-day management of the corporation and adds that if directors are men who are given supremacy over every other person in the corporation, then such persons should be people well qualified in terms of business experience, academic attainment, knowledge and skills to be well able to tackle challenging problems of such a corporation. At present, there is no statutory or common law specification of the quality of persons occupying the seats of a board room both in England and in Nigeria.

Consequently, a board, particularly in Nigeria, accommodates diverse personalities some of whom are least qualified to be on board. This is not conducive to the progress and success of most of the companies. A result-oriented board is predicted on the right calibre of men on the board. Therefore, to enhance performance and productivity, some sorts of professionalism should be introduced. Accordingly, we strongly recommend that Sections 246 and 255 of CAMA be amended to reflect this view.

It is interesting to note that fundamentally what the Companies and Allied Matters Act have done is to codify the relevant common law principles and the relevant articles in table A allowing each organ independent rights to exercise its powers unless some intervention becomes necessary in the interest of the company. Consequently, Section 63 of CAMA provides that the company shall act through:

(a) Its members in general meeting or;

(b) Its board of directors, or;

(c) Through officers and agents appointed by or under authority derived from the members in general meeting or the board of directors (S. 63(1) of CAMA, 2004).

The general meeting can also exercise the default powers of management for example where the directors are disqualified from voting (Grant V. U. K. Switchback Nway (1888) 40 Ch. D. 135), or where there are no directors, (Alexander Ward v. Samyang Navigation company (1975)1 MLR 673) or where an effective quorum of the board cannot be formed, (Foster v. Foster (1916)1 Ch 532) where there is a deadlock on the board, etc. (Baron v. Porker (1914) 1 Ch 895).

One can borrow the constitutional analogy offered by Gower to explain the relationship between the board and the members in general meeting. The general meeting can be taken to be the supreme legislative body, while the board forms the administrative arm of the company. 


\section{Who Is a Shareholder}

At common law, a person becomes a member of a company by subscribing for shares (Gower, 1997) in the company and this confers a proprietary interest in the company as well as rights and obligations to the shareholders. In Nigeria, Section 79 (1) and (2) of the Companies and Allied Matters Act, 2004 provides thus:

A person may become a member by subscribing to the memorandum of a company or by agreeing in writing to become a member of the company that is by allotment of shares.

Section 79(3) declares that in the case of a company having a share capital, each member shall be a shareholder of the company and shall hold at least one share.

It is instructive to note that being a member of a company does not however entitle the members to a portion of the company's property which belongs exclusively to the "company" a separate legal entity from its members. All he owns is shares-"a legal and economic bundle" (Manning, 1957). Under the Companies and Allied Matters Act, 2004, Section 114 (a) provides thus:

Subject to the provisions of this Act, the rights and liabilities attaching to the shares of a company shall be dependent on the terms of issue and the company's articles (CAMA, 2004: http://www.placng.org/new/laws/C20.pdf).

while sub-section 114(b) states that:

The basic rights attached to a share or shares are the rights to attend any general meeting of the company and vote at such a meeting (Cap. C20 LFN, 2004).

Other rights include the right to dividend when profits are declared, the right to inspect the book of the company and the right to share in the distribution of the company's surplus assets, if and when the company is wound-up. But it should be noted that this last right does not apply to companies limited by guarantee by virtue of Section 26(9) of the Act. Asomugha describes a shareholder as "... One who has acquired at least one of the company's shares" (Asomugha, 1968).

A company may if so authorized by its memorandum becomes a member of another company. This it can do by acquiring the shares of that other company. A company, however, cannot become a member of itself since it cannot legally acquire its shares for that purpose. Any such acquisition of shares will amount to a reduction of its capital and would also be caught up by section 160 of the Act, which prohibits acquisition of own shares (Ekpo, 2005).

\section{The Length of the Notice of Meetings}

In England, the length of notice of meetings, and how and to whom notice shall 
be given, depend primarily on the company's regulations." Section 307(1) of the English Companies Act of 2006 provides that: A general meeting of a private company (other than an adjourned meeting) must be called by notice of at least 14 days, while section 307(2) states thus: a general meeting of a public company (other than an adjourned meeting) must be called by notice of-(a) in the case of an annual general meeting, at least 21 days, and (b) in any other case, at least 14 days. By subsection 3 of the law: the company's articles may require a longer period of notice than that specified in subsection (1) or (2). On the other hand, subsection (4) of the Act provides as follows: A general meeting may be called by shorter notice than that otherwise required if shorter notice is agreed by the members. Under section 307(5) of the Act, the shorter notice must be agreed to by a majority in a number of the members having a right to attend and vote at the meeting.

In Nigeria, the length of notice for calling all types of company meetings under the Companies and Allied Matters Act, 2004 is 21 days from the date on which the notice was sent out (Section 217(1) 2004, Companies \& Allied Matters Act). It has been held that "days" means clear days that is both the day of service and the day of the meeting are excluded from the required number of days. Thus, in the English Case of Re Hectors Whailing (1939, Ch. 208), the court held that the period of not less than 21 days prescribed by Section 117(2) of the Company Act, 1929, relating to notices of meetings-together with the passing of special resolutions means a period of not less than 21 clear days exclusive of the day of service of the notice and exclusive of the day on which the meeting is to be held. It is worthy of mentioning that in every company's notice of the meeting, there must be a provision that members have the right to appoint a proxy (Section 230 (2) CAMA, 2004). Thus, precise information on proxy must be enclosed in a notice of the meeting. A breach of this constitutes an offence (Section 230 (2) CAMA). By section 230 (3) of CAMA, proxy form/instrument is to be lodged by members not later than 48 hours before a meeting or adjourned meeting. If the articles provide an earlier time, it is void. Thus, at least two clear days before the meeting is allowed for the utilization of proxy option, but no proxy is permitted within less than 48 hours ( 2 days) to the meeting unless it is an instrument in respect of poll voting which must be deposited at least 24 hours before the time appointed for taking of the poll (Section 230 (2) CAM). The legal implications of the above provisions of the law are that if the company secretary does not give the required length of notice to the members on time, this will eventually affect the concept of proxy mechanism, as members entitled to attend a company meeting but are indisposed may not have enough time to appoint a proxy to attend and vote in his stead. Failure to give notice to a person entitled shall invalidate the meeting unless the failure is accidental (Sections 228, 230 and 221 CAMA). The Supreme Court of Nigeria in the case of Longe v. F.B.N Plc (2010, 6 NWLR pt 1197) adopted the above approach in the determination of whether the aggrieved managing director of the First Bank Plc who was absent in a meeting in which a decision was taken against him was indeed served with the 
notice.

The facts of this case were that the Appellant/Plaintiff was appointed the Managing Director/Chief Executive of the Respondent (FBN) on February 24, 2000, by its Board of Directors. Before this appointment, the Appellant was the Respondent's executive director. The Appellant was accused of impropriety, following which he was suspended by the Respondent's Board of Directors on April 22, 2002, and his appointment was later revoked on June 13, 2002. The Appellant was not given the notice of the meeting of the Board of Directors of the Respondent where the decision to terminate his employment was taken. Consequently, the Appellant filed an action against the respondent contending that he was entitled to the notice of meeting by virtue of Section 266 of Companies and Allied Matters Act and failure to give him such notices rendered the termination unlawful, null and void. The trial Court dismissed the Appellant's claims. Dissatisfied with the judgment, the Appellant appealed to the Court of Appeal, but his appeal was dismissed. Still aggrieved, he appealed to the Supreme Court and contended that the Court of Appeal was wrong when it held that a meeting of directors is not within the Companies and Allied Matters Act (CAMA) and in particular within Section 266(1), and more importantly in the light of the definition of the word "director" in Section 650 of CAMA which the Court failed to consider. The Supreme Court unanimously allowed the appeal. Oguntade J.S.C. in delivering the lead judgment, held that:

By virtue of the combined provisions of section 266(1) and 262 of the Companies and Allied Matters Act, a director to be removed must be given a notice of the meeting. Therefore, failure to give such notice shall invalidate the meeting. The requirement of notice is mandatory, and the Court has no discretion to exercise in the matter where a director to be removed was not given notice of the meeting at which his removal was to be discussed.

The essence of corporate governance is to ensure that proper and right things are done in running the affairs of companies, be it appointment or removal of directors. Improper removal or election of directors would be an unhealthy corporate governance practice and Courts as can be seen from the cases examined above will frown at such practices and ensure that the affairs of corporate entities are run within the provision of the law. Such pronouncements from courts have remained the law that seeks to promote good corporate governance practice.

Also the contents of the notice of meetings according to the Act (Section 218 CAMA), must specify the place, date and time of the meeting, and the general nature of the business to be transacted thereat in sufficient detail to enable those to whom it is given to decide whether to attend or not and where the meeting is to consider a special resolution, the terms of the resolution must be set out. (Re: Moorgate Mercantile Holdings Ltd. (1980) 1 All E.R. 40) Certain ordinary resolutions require special notice, and for it to be effective, 28 days shall be given to 
the company before the meeting at which it is to be moved.

\section{Use of Proxy System}

In England, attending and voting had to be in person, but it has been recognized that these duties could be undertaken by an agent or proxy. Under Section 324 of the English companies Act, 2006, a member of the company has the right to appoint proxies. For instance, section 324(1) of the Act provides as follows: A member of a company is entitled to appoint another person as his proxy to exercise all or any of his rights to attend and to speak and vote at a meeting of the company.

Section 324(2) of the same law goes further to say that: In the case of a company having a share capital, a member may appoint more than one proxy in relation to a meeting, provided that each proxy is appointed to exercise the rights attached to a different share or shares held by him, or (as the case may be) to a different $£ 10$, or multiple of $£ 10$, of stock held by him.

In Nigeria, Section 230 of CAMA, 2004 recognizes this practice and imposes a condition to safeguard the abuse of the system.

Section 230 of the Act provides that:

Any member of a company entitled to attend and vote at a meeting of the company shall be entitled to appoint another person (whether a member or not) as his proxy to attend and vote instead of him. Such a proxy shall also have the same right as the member to speak at the meeting.

In order to remind the shareholders that they have the right to vote by proxy, Section 230(2) of the same law goes further to provide that:

...in every notice calling a meeting of a company having a share capital, there shall appear with reasonable prominence a statement that a member is entitled to appoint a proxy (or, where it is allowed one or more proxies) to attend and vote instead of him and that a proxy need not also be a member. Failure to comply with this subsection renders every officer liable to a fine of N250.00.

Furthermore, in order to protect the right of the shareholders to appoint proxies, the Act in Sub-section (3) states that any provisions in the company's articles which will avoid an instrument appointing a proxy because it was not lodged 48 hours before the meeting is void. To prevent directors from soliciting shareholders who are likely to support them for appointing them as their proxies, Section 230(4) provides that:

If for any meeting of a company invitations are issued at the company's expense to only some of the members entitled to be sent a notice of the meetings and to vote by proxy, every officer of the company who knowingly and willfully authorizes or so permits their issue shall be liable to a fine of N500.00.

In other words, the invitations must be sent to all the shareholders. These 
provisions are designed to assist the shareholders in maintaining their control over the director (even though they may not be present at the meeting) through voting by proxy, but as will be seen later this objective has never been achieved in practice.

The writer submits that the above penalties and fines of N250.00 and N500.00 respectively in both Sections 230(2) and 230(4) of the Act for every officer of the company who is in default for failure to give invitations and details to the shareholders to attend a meeting and vote in person or through his proxy are too merger to deter wrongdoing. We suggest that where an individual officer commits an offence under both Sections, he or she should be liable on conviction to a fine of not less than N10million each. We also notice that the Act in Sections 230(2) and 230(4) omit a concurrent penalty of both fine and imprisonment. It is unclear whether this omission is intentional or an omission. If it is an omission, the law should be amended to take care of this, and if it is intentional, it is contrary to the best practices.

Although the provisions relating to proxy voting give an appearance of democratic freedom, this appearance is often deceptive. In reality, the practice helps to enhance corporate powers and dictatorship by the board of directors. Our research shows that proxy voting is bedevilled with the following problems or impediments which render it ineffective:

The Chairman of the board is usually nominated as a proxy for all members in the absence of anybody representing them.

The proxy paper or instrument does not contain explicit information on how the proxy, that is, the authorization will be exercised, such as voting in one direction or the other, participating in a particular proceeding or not etc. This is particularly true with respect to the election of directors and members of the Audit Committee.

The problem of delayed notice also applies to the receipt of proxy papers which is usually sent along with notice of the meeting and the annual report. It is hardly practicable for a member to deposit a proxy form at the registered office of the company not less than 48 hours before the meeting, as required by law when the papers will usually arrive late or even after the meeting would have been held.

From the foregoing, it is doubtful whether the proxy mechanism has resulted in any substantial increase in shareholder participation in corporate governance. However, in spite of the shortcomings associated with the proxy voting system, it is argued, elsewhere that the corporate system, as it is known today, only works because the shares have voting rights and it is because of the potential exercise of those rights that shareholders can think of controlling the directors.

\section{Quorum at the General Meetings}

A quorum in law simply means the minimum number of persons entitled to be 
present at a meeting (or their proxies if allowed) which the regulations require to be present before the meeting can transact a valid business. It is the first essential requirement in holding company meetings unless the contrary is contained in the company's articles, for without a quorum no valid resolutions can be passed. In England, Section 318 of the Companies Act, 2006 provides for a quorum at meetings. Sub-section (1) of the Act states that: in the case of a company limited by shares or guarantee and having only one member one qualifying person present at a meeting is a quorum.

Subsection (2) of the same Acts provides in the main as follows: In any other case, subject to the provisions of the company's articles, two qualifying persons present at a meeting are a quorum, unless:

(a) Each is a qualifying person only because he is authorised under section 323 to act as the representative of a corporation in relation to the meeting, and they are representatives of the same corporation;

(b) Each is a qualifying person only because he is appointed as a proxy of a member in relation to the meeting, and they are proxies of the same member.

The other aspect of a quorum at meeting under the Act is to be found in Section $318(3)$ which relates to a qualifying person appointed as a proxy in relation to the meeting. This section provides to the effect that: (a) an individual who is a member of the company, (b) a person authorized under section 323 (representation of corporations at meetings) to act as the representative of a corporation in relation to the meeting, or (c) a person appointed as a proxy of a member in relation to the meeting.

Also, before now, under the wording of Tables A, (Table 1948) the English Courts held that it sufficed that a quorum was present at the time when the meeting began, (Re Hartley Baird Ltd (1955) Ch. 143,) even though some members left before all the business had been conducted (provided that at least two remained so that it could still be regarded as a meeting).

In Nigeria, the Companies and Allied Matters Act have reconciled these obviously conflicting provisions. Section 232(1) of the Act states that: unless otherwise provided in the articles, no business shall be transacted at any general meeting unless a quorum of members is present at the time when the meeting proceeds to business and throughout the meeting.

Although it is admitted that there is a general apathy amongst shareholders in attending meetings of the company it leaves much to be desired (and one can, in fact, say that it is against democratic principles) that only two or three members of a company, whose membership may run to about 3000 may bind the company with resolutions passed at such meetings. It is suggested that the law should provide that at least one quarter (25\%) of all members shall be present before a quorum is formed, although the meeting can be held with the number of members present (not below 10\% of the company's membership) where the meeting had to be adjourned thrice on the ground that a quorum could not be formed. 


\section{Directors Disclosure of Information to Shareholders}

In the preceding paragraph, it would be observed that the general meeting serves as a forum for shareholders to air their views on company management and take necessary action within their powers if not satisfied with company policies, practices or even its officers (Barnes, 1992). But in practice, it seems the shareholder's control of the affairs of the company is determined by the directors. This is so because the directors as the "alter ego" of the company, of course, have inside knowledge of the affairs of the company and they have effective control over the calling of company's meetings and proxy machinery which is one of the checks envisaged upon the power of the general meeting over corporate management.

However, to checkmate this ugly development, the CAMA has made provisions to ensure that relevant information needed by the shareholders in order to exert effective control over the activities of the company and management and to participate effectively in the company meetings are reasonably made available to them by the directors. Thus, in Nigeria, the CAMA, just like the English companies Act of 2006, makes it mandatory for certain disclosure to be made by the directors. For instance, the Act makes it compulsory for directors to make certain disclosure by directors of their interests in contracts. (Section 277 of CAMA) Also, Section 340 and 341 of CAMA make it mandatory for the directors to lay before the Annual General Meeting all loans and remunerations in favour of directors and other officers of the company including managers and secretaries (Olakanmi, 2006).

Similarly, Section 334 makes it mandatory that every company is required to keep "accounting records" for what the company directors will use in the preparation of financial statements of profit and loss account in which he would lay before the company in the general meeting. The financial statements must include, among others, the balance sheet and profit and loss accounts; the sources and application of funds giving information about generation and utilization of fund; the value-added statement reporting, the wealth created by the company during the year. These statements must rich the shareholders, who must decide whether to approve or reject the financial statement, at least 21 days before the annual general meeting.

Furthermore, 315 provide for the right of the individual shareholders to demand an investigation of the affairs of the company. Apart from the Companies Act, part C Section 21.3 of the SEC Code states that:

A company's directors have the duty to disclose relevant information in relation to any proposal to be considered at a general meeting. The law goes further to say that the directors are required to make full disclosure of all facts within their knowledge which are material to enable the shareholder to determine which course of action to take. The director should provide material information as willfully and fairly inform shareholder of what is to be considered at the meeting and for which their support is sought.

To this extent, it is clear that part of shareholders' democracy implies disclo- 
sure to members, vital information relating to the company before any meeting so that they may judge for themselves whether to leave the matter to be determined by the majority attending and voting at the meeting.

Though the CAMA is silent on the level of information to be available to the shareholders or the type of dialogue or interaction that should go on between the shareholders and the director, the Codes are quite clear, that all facets of the board ought to be involved in the dialogue and should be available at all times to allay fears and explain concerns of the shareholders. It will be open to the shareholder activist to ascertain the adequacy of the information provided by the directors at a general meeting concerning a resolution placed on its agenda. The shareholders may refuse to vote or approve resolutions and motions without adequate and material information to assist the shareholders in forming a responsible opinion as to their decision on the matter before them.

\section{Summary of Findings}

1) This paper found that shareholders have not been able to exercise meaningful control over the calling of the company's meetings which is one of the effective machinery in their hands to control the activities of the directors. This is so because, for the general meeting to be valid, it must be properly convened, and the particular agenda must be properly placed on the agenda of the meeting by the directors. However, the directors have the exclusive power to determine the time to fix the meeting, the venue where it would hold, items or issues to be placed on the agenda, and notices to the members about the meeting. From the foregoing, it is clear that the shareholders have no power to convene the meeting except through court order, or when the directors refuse or neglect to do so. This being the case, there is every tendency that the directors may deliberately decide not to include in the agenda any matter which may adversely affect their interest whether company suffers or not, provided that their interest is protected.

2) As a result of the above findings, the paper further found that the directors may purposely fix the date for the Annual General Meeting (AGM) of the company when it would not be advantageous for the larger part of the individual shareholders to attend the meeting. For example, during Christmas, Easter and Sallah, periods in Nigeria, knowing too well that most of the individual's shareholders will commend the commemoration in inclination to going to the meeting. The executives may choose the setting for the meeting. The directors may select the venue for the meeting at a very far distance so that the majority of the members are disenfranchised. Even the minority who dare to attend despite all odds will have to pay excessively to get to the venue. We submit according to (Dorothy, 2015) that section 216 of CAMA which provides for the holding of Annual General Meetings in Nigeria should be amended to provide for the specific venue for the meetings of the company, as company directors now hold meetings outside usual rendezvous, for instance, holding of such meetings in Lagos, Abuja or Ibadan, and by so doing, disenfranchise a great number of their 
shareholders who would normally have attended and vote at such meetings (Dorothy, 2015).

3) The paper further found that the rivalry between the board of directors and shareholders usually arises because their interests in the company in most cases are not necessarily the same. For instance, the Manager, where they are not constrained, are only interested in expanding the firm thus, investing back profit as against declaring dividends, and also enhancing their career, but generally, the shareholders are interested in profit maximization and the overall success of the company. This was the issue canvassed in the case of Nsirim v. Onuma Construction Company (Nig) Ltd. (Nsirim, 2001)., a director converted the company business to his personal interest without any consideration for the shareholders just because he was a director. This brings to fore that directors and shareholders often have rivalry between their interests in the company. On that premise, these writers are of the opinion that the relationship between the director and shareholders is that of strange bedfellows working as a team but actually and in fact on cross purposes.

4) The paper has further found that apart from the difficulty in gaining a majority for the necessary votes, shareholders run head-on into the normal corporate law rule that an amendment to the articles may be initiated only by the directors (Chrisantus, 2019

https://www.projecttopics.org/supervisory-role-of-general-meeting-over-boardof-directors-in-nigeria.html). Directors may not be willing to initiate an amendment that will curb, or restrain their powers. Even where the articles allow the shareholders to amend the articles, they may not do so to make an ordinary business decision, or to establish corporate policy. That power belongs to the directors (Chrisantus, 2019

https://www.projecttopics.org/supervisory-role-of-general-meeting-over-boardof-directors-in-nigeria.html). It can only be taken from them by a contrary provision in the articles of incorporation, and the directors' management authority extends to presiding and controlling the agenda of the shareholders meeting.

In this precarious situation, these writers associate himself with the question asked by William Shakespeare: "if correction lies in the hands of those that committed the offence, then, to whom shall we complain about the solution". Shareholders are relying exclusively on the board of directors to do business. We submit that the bane of shareholders' difficulties is their exclusive dependent on directors.

\section{Conclusion}

This paper has attempted to highlight the concept and practicability of Shareholders' democracy in Nigeria. It is clear that several measures put in place to ensure the success of shareholders control over the administration of the company are with practical difficulties. This is due to the fact that the directors who control the day-to-day affairs of the company also control the machinery for 
company meetings, which meetings reside in shareholders' involvement in corporate governance. These difficulties are found in convening the company meetings, issuance of notices of meetings, length of notice of meetings, proxy voting machinery and director's disclosure of information to the shareholders. From what has been said, one may be tempted to come to the conclusion that in practice, shareholders' democracy is not a reality in Nigeria, but that notwithstanding as earlier pointed out, there are indeed massive provisions in our laws to guarantee shareholders' democracy. The emphasis on the weakness in the enforcement is not to say that the controls have altogether been ineffective. The concepts of corporate governance have been working well in a good number of cases. Mention must be made that a large number of companies in Nigeria are glorified partnership with members also constituting the board; this does not altogether eliminate control problem, but it may be reduced. However, there are a sizeable number of companies too which are public limited liability companies with a widespread membership structure; hence the issue of control still deserves reasonable attention.

This work also established that although the General Meeting has afforded the shareholders an opportunity to supervise the management of the company in so many ways such as the power to approve the remuneration of auditors, the power to institute legal proceedings to prevent the directors from entering into ultra vires contracts, the power to declare dividends, presentation of financial statement and report of Directors and auditors, elections of directors in place of retiring ones, the power to approve increase and reduction of share capital, the power to transfer of shares, and power to ratify the directors' decision etc., as indicated in this paper. Our research reveals that it is not enough for the shareholders to be given the opportunity to perform the above legislative functions. The problem with most companies in Nigeria is that while the board of directors recognizes the important role of shareholders in corporate governance, the requisite flow of information is never given and the shareholders are most often than not always prevailed upon by the directors to approve of actions and decisions blindly. It is a settled law that the directors are to keep the shareholders well informed about the activities of the company so that the shareholders form a responsible opinion as to their decision in the matter before them. We submit that inadequacy disclosure of information by the directors to shareholders also rub them of effective control over the activities of the company.

The work further indicated that in spite of the legislative provisions on shareholders participation and involvement in the management of companies in $\mathrm{Ni}$ geria, the practice is that shareholders are generally inactive, passive and generally disinterested in the management of their companies leaving the directors to have a free day. For instance, a shareholder with small holdings may not have sufficient money, time and interest to attend general meetings. To assist people like this, the CAMA should be amended to give every shareholder a right to vote through post and E-mail. This system is workable in America. These writers are hopeful that if such a system is introduced in Nigeria, a greater percentage of 
shareholders shall be able to vote effectively in the decisions making and running of the company.

This study further proved that shareholders apathy is evident mainly because of the feeling of frustration as they believe that the directors will always have their way notwithstanding their opposition to a management decision, this is coupled with the near lack of knowledge of the legislative provisions safeguarding their interest and avenue to exercise their powers within the company. It should be made clear that the days of inactive shareholders involvement in corporate governance should end and using some of the recommendations proffered here in this paper, good corporate governance will be further and better enhanced.

\section{Recommendations}

In recommending measures to better shareholders' control over the board of directors in modern corporate governance in Nigeria, it is the belief of the writer that nothing much can be gained from disregarding what is presently provided for in the companies and Allied Matters Act; rather, recommendations shall be made for the amendment of our law to enable both the shareholders in the General Meeting and the Board of directors to provide effective leadership to the companies so that they can deliver on their promise, as the wealth-creating organ of society, and to do so in a sustainable manner. Accordingly, we proffer the following recommendations:

1) For the supervisory role of the members in the company meetings to serve the desired goal, which is primarily to checkmate the director's excesses and to make the company result-oriented, the power vested in the directors should be divested to the general meeting. The power to convene the company meetings, issuance of notices of meetings, and proxy voting machinery should be vested in the shareholders in the general meeting because, they are the only financially interested party, as well as the owner of the company. When this is done, shareholders will be active in the affairs of the company, attending meetings with the aim of positive contributions during any debate and not just to receive dividends and raise hands during voting. The shareholders who are the owners should be in control of the directors who were appointed by them if they are to avoid a situation where the employee is dictating to the employer.

2) Attention should be directed at ensuring that the shareholders exercise meaningful control over the activities of the directors. This could be possible if the present voting system should be replaced and substituted with a system under which shareholders would be allowed to vote by a postal ballot or through their recognised E-mail and text messages. The present system whereby a shareholder must attend meeting in person or through his proxy should be discouraged. It must be understood that presently, the problem faced by most of the shareholders is their inability to attend meetings and participate effectively in the resolutions and making of the company's decisions.

We submit that since the notice of every meeting always spells out the nature 
of the business to be transacted and if thought fit, pass the resolutions and or decisions. Section 230 of the Companies and Allied Matters Act should be amended to dispense with the proxy system and or physical attendance and voting at the meeting. For instance, a civil servant from Akwa Ibom State of Nigeria who is a shareholder with small shareholdings might not have sufficient money, time and interest to attend the extra-ordinary or general meeting of his company in Abuja. It may be difficult for this man to leave his work and family to attend his company's meeting. To attend a meeting, he must consider his travelling, catering and lodging expenses. To assist people like this, we strongly recommended that the Act should be reviewed to give every shareholder a right to vote through post or their recognized E-mail or text messages. This system is workable in America. It is hoped that if such a system is introduced in Nigeria, a greater percentage of shareholders shall be able to participate effectively in the decision making of their companies.

3) This paper shows that corporate management recognizes two main groupings in the corporate set up as having the directing mind and will of the company, namely, the board of directors and the shareholders in general meetings. The work goes further to show that presently, the board of directors has supremacy over the general meetings in matters of the day-to-day management of the corporation. Our concern is that if directors are men who are given supremacy over every other person in the corporation, then such persons should be people well qualified in terms of business experience, academic qualification, knowledge and skills so as to be well able to tackle difficult problems of such company. At present, there is no statutory specification of the quality of persons occupying the seats of a board room in Nigeria. Consequently, a board accommodates diverse personalities, some of whom are least qualified to be on aboard. This is not conducive to the progress of a company. A result-oriented board is predicated on the right calibre of men on the board. Therefore, to enhance performance and productivity, some sorts of professionalism should be introduced. Accordingly, we strongly recommend that sections 246 and 255 of Companies and Allied Matters Act be amended to reflect this view.

4) The length of notice required for a company's meeting should be increased to 30 days to take care of the lapses usually recorded on the part of NIPOST (postal service providers).

5) The proxy voting form should be more explicit about attracting due attention of shareholders and enabling them to take the right decision.

\section{Conflicts of Interest}

The authors declare no conflicts of interest regarding the publication of this paper.

\section{References}

Adegbite, E. et al. (2010). Political Analysis of Shareholder Activism in Emergent Democracies: A Case Study of Nigeria (pp. 1-24). CSGR Working Paper 265/10, London: 
United Kingdom.

Akindele, S. T. (1994). Democracy and Imaginary Thinking in Nigeria: A Critical X-Ray of Issues and Facts in Democratization in Africa (Vol. 1, pp. 70). Benin City.

Amupitan, J. (2008). Corporate Governance: Models and Principles. Abuja: Hilltop Publishers.

Arden, M., \& Arden, M. (2016). Companies Act, 2006. Common Law and Modern Society (pp. 220-236).

Asomugha, E. M. (1968). The Shareholders, His Rights and Liabilities under the 1968 Companies Act. Nigerian Law Journal, 7, 100.

Barnes, K. (1992). Cases and Materials on Nigerian company Law (pp. 167). Ibadan: OAU Press.

Chrisantus (2019).

https://www.projecttopics.org/supervisory-role-of-general-meeting-over-board-of-dire ctors-in-nigeria.html

Dorothy, N. (2015). The Dilemma of the Shareholders under the Nigerian Company. Journal of Law, Policy and Globalization, 37, 90

Ekpo, M. (2005). Company Law and Management Practice (pp. 145). Calabar: University of Calabar Press.

Garner, A. (2004). Black's Law Dictionary (7th ed., pp. 444). St. Paul, MN: West Group Publishers.

Gower, L. C. B. (1997). The Principles of Modern Company Law (4th ed., pp. 152). London: Sweet \& Maxwell Limited.

Hornby, A. (2000). Oxford Advanced Learners Dictionary (6th ed., pp. 1072). Oxford: Oxford University Press.

Manning, H. (1957). Note. Yale Law Journal, 67, 1477-1496. https://doi.org/10.2307/794012

Nsirim v. Onuma Construction Company (Nig) Ltd. (2001). All NLR. vol. 6, p. 437.

Olakanmi, O. (2006). Companies and Allied Matters Act Cap C20 LFN. Lagos: Law Lords Publications.

Onuoha, R. (2015). The Need for Investors' Vigilance in Corporate Governance. http://www.proshareng.com/ardticles/singleNews.php?id=635

Onyekelu, A. M. (2019). Supervisory Role of General Meeting over Board of Directors in Nigeria.

Orojo, J. C. (1992). Company Law and Practice (4th ed., pp. 274). Lagos: Mbeyi \& Associates Ltd.

Pranchi, J. (2015). The Relationship between the Board of Directors. https://www.managementstudyguide.com/board-of-directors-and-management.htm 


\section{Companies Act}
1) English Companies Act, 2006 (c.46)
2) Table A 1948, at p. 53
3) Companies and Allied Matters Act, cap. C20 LFN, 2004
4) Section 63(1) 1990 Companies Act
5) Section 262 of the Companies \& Allied Matters Act, 2004
6) Section 262(1) of the Companies and Allied Matters Act, 2004
7) Section 248 CAMA
8) Section 249 (1) (2) and (3) CAMA, Cap. 20 LFN, 2004
9) Section 213 (2) of CAMA
10) Section 211, CAMA
11) Sections 212 and 408 (b) CAMA.
12) Section 211 (2) and (3) of CAMA.
13) Sections 228, 230 and 221 CAMA
14) Section 218 CAMA
15) Section 277 of CAMA

\section{Cases}

(1) Automatic Self-cleaning Filter Syndicate v. Cunningham (1906) 2 C.H. at p. 34

(2) Alexander Ward v. Samyang Navigation company (1975)1 MLR 673

(3) Baron v. Potter (1914) 1 Ch. 895, Foster v. Foster (1916) Ch. 532

(4) Baron v. Porker (1914) 1 Ch. 895

(5) First Bank of Nigeria PLC v. TSOKWA (2003) FWLR (pt. 153)205 at 235 $\mathrm{CA}$

(6) Foster v. Foster (1916) 1 Ch 532

(7) Gramophone and Typewriters Ltd v Stanley (1908) 2 K.B 89

(8) Grant, V. U. K. Switchback Nway (1888) 40 Ch.D. 135

(9) Isle of Wright Rly v. Tahourdin (1883) 25 Ch.D. 320

(10) Isle of Wright Rly v. Tahourdin (1883) 25 Ch.D. 320 (1883) 25 Ch.D. 320, CA

(11) Iwuchukwu v. Nwizu (1999) 17 NWLR (pt. 357)

(12) Iwuchukwu v. Nwizu (1999) 17 NWLR (pt. 357)

(13) Longe v. F.B.N (2010) 6 NWLR (pt. 1189) 1 at 43

(14) Marina Nominee Ltd v Fed. Board of Internal Revenue (1986) 2 NWLR (pt. 20) 48 at p, 61

(15) Nsirim v. Onuma Construction Company (Nig) Ltd. (2001) All NLR vol. 6, p.437

(16) Okeowo v. Milgore (1979) 11 S.C. 138

(17) Per Buckley, J. in Re Stanley (1906) 1 Ch. 131 or 134

(18) Quin \& Axtens v. Salomon (1908) Ch 311

(19) Re Hectors Whailing (1939) Ch. 208

(20) Re Moorgate Mercantile Holdings Ltd. (1980) 1 WLR 277; (1980) 1 All 
E.R. 40

(21) Re Hartley Baird Ltd (1955) Ch. 143, not following Henderson v. James Outtit \& Co, Ltd (1894) 21 R 674 Sc

(22) Re Dahiru Wada, (2000) FWLR (pt. 18) 214 at pp. 229-233

(23) Salomon v. Salomon (1897, A.C. 22)

(24) Scott v. Scott (1943) 1 All E.R. 582

(25) Shaw \& Sons (Salford) Ltd. v. Shaw (1937) 2 K.B. at p.113

(26) Show v. show (1953) 3 K.B 113; Scoatt (1943) 1 All E. R. 582; Bamford v. Bamford (1968) 3 W. LR. 317; Marshall Valve Gear Co. Ltd. v Manning Wardie \& Co. Ltd. 19091 ch 287

(27) Yalaiju Amaye v. AREC (1990)4 NWLR (pt. 145) 422

(28) Stephen Idugboe v. Arof Roz \& Ors (1978) 6 FCA 